\title{
The Moderating Role of Government Policies on the Relationship between Technology, Innovation and Entrepreneurship Development in Nigeria: A Partial Least Square Approach
}

\author{
Oyekunle Oyelakin*, Usman Mamman Kandi
}

Department of Business Administration, Ahmadu Bello University, Nigeria

Copyright $\odot 2017$ by authors, all rights reserved. Authors agree that this article remains permanently open access under the terms of the Creative Commons Attribution License 4.0 International License

\begin{abstract}
Given the economic realities in Nigeria, the country must constantly create new jobs, and diversify the industrial and commercial sector to take advantage of human and natural resources through entrepreneurship development. The present research aims to identify the role of government policies on the relationship between innovations, technology and entrepreneurship development in Nigeria. Questionnaire was distributed to Small and Medium Scale Enterprises (SMEs) in Osun State. Structural Equation Model was used to analyze data using Partial Least Square Method (PLS 3). The results based on findings shows that a positive significant effect was found between government support, innovation and technology on entrepreneurship development. Government policies were found to have fully moderate the relationship between innovation, technology and entrepreneurship development. Government polices was found to be the most explanatory variable of the study having the highest effect on the entrepreneurship development. Therefore, the study recommends that government should enact policies that will encourage and promote the use of technology and support innovative ideas to bring economic growth through entrepreneurship development.
\end{abstract}

Keywords Entrepreneurship, Development, Government Policies, Technology, Innovation

\section{Introduction}

In Nigeria, shaping the future beyond oil is a critical part of the national agenda. The current economy is dominated by the oil industry. The labour force of 47 million is growing, as the unemployment rate currently at $20 \%$, with millions of workers underemployed. Nigeria has the largest domestic market in Africa, a wide range of natural resources, and a diversely skilled labour pool. Given these economic realities, the country must constantly create new jobs, and diversify the industrial and commercial sector to take advantage of human and natural resources through entrepreneurship development. The importance of entrepreneurship development in several economies globally cannot be overemphasized; as such majority of countries worldwide have established programmes to support entrepreneurship in their various countries (Gangi \& Timan, 2013). It has been established that entrepreneurship is an instrument for creating job as well as economic development (Friedman, 2011). Entrepreneurship serves as a source of income generation for major group both rural and urban inhabitants without recognized paid job (Ihugba, Odii, \& Njoku, 2014) and also serves as an element of change and transformation of economic, culture and society development (Moghimi 2008).

Similarly, in Nigeria, over the past three decades, government evolved policies and programmes aimed at developing entrepreneurship through the development of small and medium scale enterprises (SMEs). Entrepreneurship is related to small business. Certainly, small firms are driver for individuals to channel their entrepreneurial ambitions through creation of new enterprises, new commercial activities, new economic sectors, generate jobs for others, produce goods and services for society, introduce new technologies, substitution of imports, mobilize domestic savings and utilization of local resources through foreign exchange export.

The greatest economies of the world today and emerging nations are being driven by technology and innovation (Akande \& Oladejo 2013). It is imperative to note that innovation and technology are needed to transform 
countries and form a base for development (Sharma \& Bhagwat 2006). The involvement of developing countries in producing new technologies and innovations is almost negligible (Juma \& Agwara, 2006). In the view (Khanduja et al., 2008) argued that technology have been responsible for creating wealth, jobs and help to reduce business failure rate. Countries like US, Israel and China have been successful through the proper use of technology. Reverse is the case in Africa, Nigeria precisely, it has been observed and documented that there is an apparent dearth of technology entrepreneurship capital which has led to the near non-existent productive capacity of the continent, with very minimal potentials for value addition (Bubou \& Siyanbola 2010). Therefore nurturing technology based enterprises will improve the country economy and perhaps moved a step closer to development (Kark, 2003).

Innovations on the other hand have proven to be crucial components for the entrepreneurship development of modern societies (Akande \& Oladejo, 2013). The dictionary defines innovation as the introduction of something new or different. According to Okpara (2007) defines innovation as a process of bringing the best ideas into reality, which triggers a creative idea, creating new values, transforming ideas into value and generates series of innovative events. In other word, innovation is the introduction of new ideas, goods, services, and practices which are intended to be useful. The main driver for innovation is often the courage and energy to better develop the world, an essential element for innovation is its application in a commercially successful way (Bulsara \& Gandhi). Innovation according to Amue, Igwe and Abiye (2014) is a catalyst for the growth and success of business to grow in the marketplace. Incorporating innovation in business can help save time, money and give business competitive advantage to grow and adapt in turbulent environment.

Government policies affect entrepreneurship development directly and indirectly (Tende 2014). Government regulations and their bureaucratic procedures can hinder as well as facilitate entrepreneurship activity (Sathe 2006). Governments through their laws, regulations, investments, and other policies create a considerable impact on where entrepreneurs choose to establish new enterprises and the probability that those enterprises will succeed (Bhat and Khan 2014). In other words government policies can boost business growth or otherwise. Although in Nigeria there are already existing governmental policies and activities designed to support/spur entrepreneurship development in Nigeria, policies were formulated in relation to financing, taxation, regulations on trade, and encouragement of innovation activities. Etc. But despite recent achievements that prove Nigeria potential for entrepreneurial triumph, there is little doubt about the severity of constraint on the road ahead.

Nigeria is not perceived as a promising business destination due to the high cost of doing business, corruption and systemic flaws in the country economic policies have cumulatively succeeded in keeping off potential investors. Massive infrastructural deficits, particularly with regards to roads and electricity, are further turnoffs. The most significant aspect of the problem, however, is Nigeria nascent and shaky polity, constantly under threat from civil intolerance and rising religious extremism. Social problems, growing out of deplorable human development indicators in the absence of inclusive growth, form the second significant obstacle for Nigeria. The status of women and their traditionally limited involvement in entrepreneurial activities is a significant drawback from the perspective of rapid social and economic growth.

Giving the generally held view that entrepreneurship development is the key to economic growth and development. The present study examined the moderating role of Role of Government Support on the Relationship between Leveraging Technology, Innovation and Entrepreneur Development in Nigeria.

\section{Literature Review}

\section{Empirical Review}

Few empirical literatures were conducted in relation to technology, innovation and entrepreneurship development. Hussain, Afzal, Asif, Ahmad and Bilal (2011) conducted a study on the impact of innovation, technology and economic growth on the entrepreneurial activities. The results showed that these variables are highly correlated with the dependent factor Entrepreneurship. Also in the study conducted by Hosseini, Lashgaara and Hosseini (2014) identify the role of information and communications technology (ICT) on entrepreneurship development regarding experts' views of Agriculture organization in Tehran. The results showed that the capabilities of ICT are significant on entrepreneurship development. In the study of Goutam and Sarkar (2015), focuses on the development of technology and its positive effects on the entrepreneurial development especially in Indian context. Findings indicate that technology is an accelerator in development of innovative ventures and hence the economic development of a country. However the studies are conducted in foreign countries, therefore the need to conduct similar studies in Nigeria since differences in economy is a significant gap in the literature according to $\mathrm{Li}$ and $\mathrm{Liu}$ (2014).

In Nigeria, Siyanbola, Aderemi, Egbetokun and Sanni (2011) presented a framework for developing technological entrepreneurship particularly for developing countries, with supporting policy directions. The framework stresses the fact that the innovation process is facilitated by technological entrepreneurship which is in turn pre-conditioned within the context of favorable 
policies, institutions, financial and institutional support. Obaji and Olugu (2014) also develop a conceptual framework that examines the role government policy plays in the development of entrepreneurship and its impact on economic development. The study builds on existing literature on entrepreneurship, economic development and government policy as it relates to entrepreneurial practices. This study only presented a conceptual framework and called for justification of measurements, structural model as a direction for further research.

Also in Nigeria, Akande, and Oladejo (2014) assessed whether participation in technological entrepreneurial development programmes has positive impact on the performance of SMEs in Lagos state. The result of the analysis and the hypotheses tested showed significant and positive impact of technology entrepreneurship development programmes on the performance of the participating small businesses. Also Oyewale, Adeyemo and Ogunleye (2014) analysed the impact of innovation, technology and on the entrepreneurial development activities in Nigeria. Results showed that there is significant relationship between technological innovation and entrepreneurship development in Nigeria. Amue, Igwe and Abiye (2014) examine the link between ICT entrepreneurship and small business innovation. In particular, the authors develop a conceptual model arguing that regulatory environment on ICT entrepreneurship development influence small business innovation. A model was proposed to form a richer theoretical framework that guides the understanding, explanation and prediction of innovativeness in ICT entrepreneurship. However this studies were conducted when the economy is relatively stable, as observed by Aminu (2015) conducting a similar study in turbulence environments as the case was in Nigeria presently is another significant contribution to the body of knowledge.

Onwuka, Ugwu and Kalu (2014) investigate the impact of policy measures in entrepreneurship development in Nigeria. The study found that Nigeria's entrepreneurs have experienced difficulties in doing business due to: technological problems and lack of credit facilities. Tende (2014) examines various government policies and programs towards the development of entrepreneurship in Nigeria. The result shows that government credit policies and programs have no significant effect on the development of entrepreneurial beneficiaries.

In view of the empirical literature reviewed, this study has considered to test the moderating role of government support on the relationship between technology, innovation and entrepreneurship development.

\section{Theoretical Framework}

The origin of entrepreneurship theory can be trace back to Richard Cantillon. The first is the German school by Schumpeter and Baumol, the second is the neoclassic school of Marshal, Knight and Schultz and the third is the Austrian managerial school of Von Mises and Krizner. The schools of thoughts shares common language but differ in aspect of entrepreneur's performance. In Schumpeter or German school, economists insist on entrepreneur as a creator of instability.

Consequently, the present study has adopted Schumpeter entrepreneur theory to underpinned it model as shown below

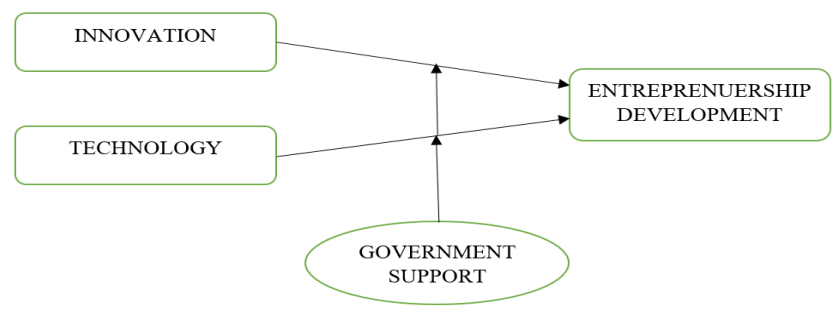

Figure 1. Model for the study

The model depicts a relationship amongst the key variables that affect entrepreneurship development in Nigeria. The framework is developed to test the moderating role of government support on the relationship between innovations, technology and entrepreneurship development in Nigeria.

\section{Research Methodology}

This study was conducted as a cross-sectional survey research which is designed to obtain pertinent information concerning the current state of affairs. The population of the study consists of 2,272 SMEs (2,247 Small and 25 Medium scale enterprises) operating businesses within Osun State. The number of SMEs was obtained from SMEDAN and National Bureau of statistics Collaborative Survey (2013). The sample size was determined using Krejcie and Morgan's (1970) table. 348 sample size against a population of 2,272 registered SMEs. However, $20 \%$ of the minimum sample provided in the formula will be added as suggested by Israel (2013) to take care of non-response bias and improper filling of questionnaire, bringing the total sample size to 418 .

Primary source of data was used in the study to examine the moderating role of government policies on the relationship between technology, innovation and entrepreneur development in Nigeria. Primary data was obtained through the use of self-administered questionnaires to business owners/managers using simple random sampling technique. The measurement for each of the variables was adapted from different authors. Additionally, content validity was used to validate each statement of the instrument based on the evaluation of the two experts in the management field.

Data were analysed using Partial Least Square (SmartPLS 3) and followed the two-stage approach for 
assessing the measurement model and the structural model respectively. According the suggestions of Urbach and Ahlemann (2010), this study tested the important criteria and processes to estimate the outer and inner model.

\section{Data Analysis}

The total of 418 questionnaires was distributed and 371 were retrieved. Data screening was carried out on the 371 retrieved questionnaires out of which 342 were found to be useful because of being correctly filled. Thus the analysis was based on 342 questionnaires duly filled and returned which represent of the total questionnaire distributed.

Table 1. Summary of Responses

\begin{tabular}{|c|c|c|}
\hline Items & No of Copies & Percentage \\
\hline No of Questionnaire Distributed & 418 & 100 \\
\hline No of Returned Questionnaire & 371 & 88.7 \\
\hline No of Useful Questionnaires & 342 & 81.8 \\
\hline
\end{tabular}

From table 1, the no of useful questionnaire is 342 $(81.8 \%)$ which is a response rate considered sufficient for statistical reliability and generalization (Tabachnick \& Fidell, cited in Aminu, 2015).

Table 2. Descriptive Statistics

\begin{tabular}{|c|c|c|c|}
\hline Characteristics & Frequency & Percentage & $\begin{array}{c}\text { Cumulative } \\
\text { percentage }\end{array}$ \\
\hline Gender & & & \\
\hline Male & 245 & 71.6 & 71.6 \\
\hline Female & 97 & 28.4 & 100.0 \\
\hline Age & & & \\
\hline $18-25$ & 12 & 3.5 & 3.5 \\
\hline $26-35$ & 109 & 31.8 & 35.3 \\
\hline $36-45$ & 123 & 35.9 & 71.2 \\
\hline 46 and above & 98 & 28.8 & 100.0 \\
\hline $\begin{array}{c}\text { Educational } \\
\text { Qual. }\end{array}$ & & & \\
\hline SSCE & 04 & 1.2 & 1.2 \\
\hline OND/NCE & 89 & 26.0 & 27.2 \\
\hline B.Sc. & 194 & 56.7 & 83.2 \\
\hline MSc. / Ph.D. & 55 & 16.8 & 100.0 \\
\hline
\end{tabular}

Table 2 above, presents the gender distribution of the respondents. $71.6 \%$ of the respondent was male while the remaining $28.4 \%$ were Female. This implies that there are more male entrepreneurs than female entrepreneur.

The age distribution was also presented in table $2.3 .5 \%$ were of age between $18-25$ years, $31.8 \%$ were of age $26-$ 35 years, $35.9 \%$ were of age $36-45$ years and $28.8 \%$ were of age 46 years and above. This implies that most of the respondent is of age between $36-45$ years.

The education qualification of respondent was also presented. $1.2 \%$ of the respondent have SSCE has their maximum qualification, $26 \%$ has $\mathrm{OND} / \mathrm{NCE}, 56.7 \%$ has B.Sc. and $16.8 \%$ has MSc. / Ph.D. This indicate that most of the respondent has B.Sc. has minimum qualification.

Table 3. Construct Reliability and Validity

\begin{tabular}{|c|c|c|c|c|c|}
\hline Construct & Items & Loadings & AVE & CR & CA \\
\hline \multirow{3}{*}{ Entrepreneurship } & ETD1 & 0.698 & & & \\
Development & ETD2 & 0.801 & & & \\
& ETD4 & 0.767 & 0.758 & 0.865 & 0.819 \\
& ETD5 & 0.724 & & & \\
\hline \multirow{2}{*}{ Government } & GTS1 & 0.513 & & & \multirow{2}{*}{0.753} \\
Policies & GTS2 & 0.915 & 0.628 & 0.828 & \\
\hline \multirow{2}{*}{ Innovation } & GTS3 & 0.886 & & & \multirow{2}{*}{0.900} \\
\hline \multirow{2}{*}{ Technology } & INN3 & 0.733 & 0.985 & 0.812 & \multirow{2}{*}{0.897} \\
& TEC1 & 0.859 & & & \\
\hline
\end{tabular}

Note: AVE represents Average Variance Extracted; CR represents Composite Reliability; CA represents Cronbach's Alpha

Table 3 above shows the Factor Loading, Cronbach Alpha, Composite Reliability (CR) and Average Variance Extracted (AVE) values for all latent constructs after Pooled CFA has been performed. All constructs have achieved the minimum estimation required; 0.70 (Cronbach Alpha), 0.60 (CR) and 0.50 (AVE). Therefore, it can be concluded that Convergent Validity (AVE _ 0.5), Internal Reliability (Cronbach Alpha _ 0.6) and Construct Reliability (CR_ 0.60$)$ of all constructs had been achieved. Therefore, the model is good enough for the analysis.

Table 4. Fornell-Larcker Discriminant Validity

\begin{tabular}{|c|c|c|c|c|}
\hline Construct & Ent Dev & $\begin{array}{c}\text { Gov. } \\
\text { Policies }\end{array}$ & Innovation & Technology \\
\hline Ent. Dev. & $\mathbf{0 . 8 0 5}$ & & & \\
Gov. Policy & 0.260 & $\mathbf{0 . 7 9 3}$ & & \\
Innovation & 0.750 & 0.420 & $\mathbf{0 . 8 2 8}$ & \\
Technology & 0.781 & 0.212 & 0.688 & $\mathbf{0 . 9 1 1}$ \\
\hline
\end{tabular}

The Fornell-Larcker criterion (1981) is a common and conservative approach to assess discriminant validity and it can be applied in PLS-SEM. The diagonal value (in bold) is the square root of AVE, while other values are the correlations between the respective latent construct. The discriminant validity is achieved when a diagonal value (in bold) is higher than the values in its row and column. Referring to the above table 4, it can be concluded that discriminant validity for all constructs are achieved.

\section{Bootstrapping Analysis (Structural Model)}

Bootstrapping analysis is conducted to determine the direct effect. This was done by using 5000 subsamples with 342 cases as presented in figure 2 . 


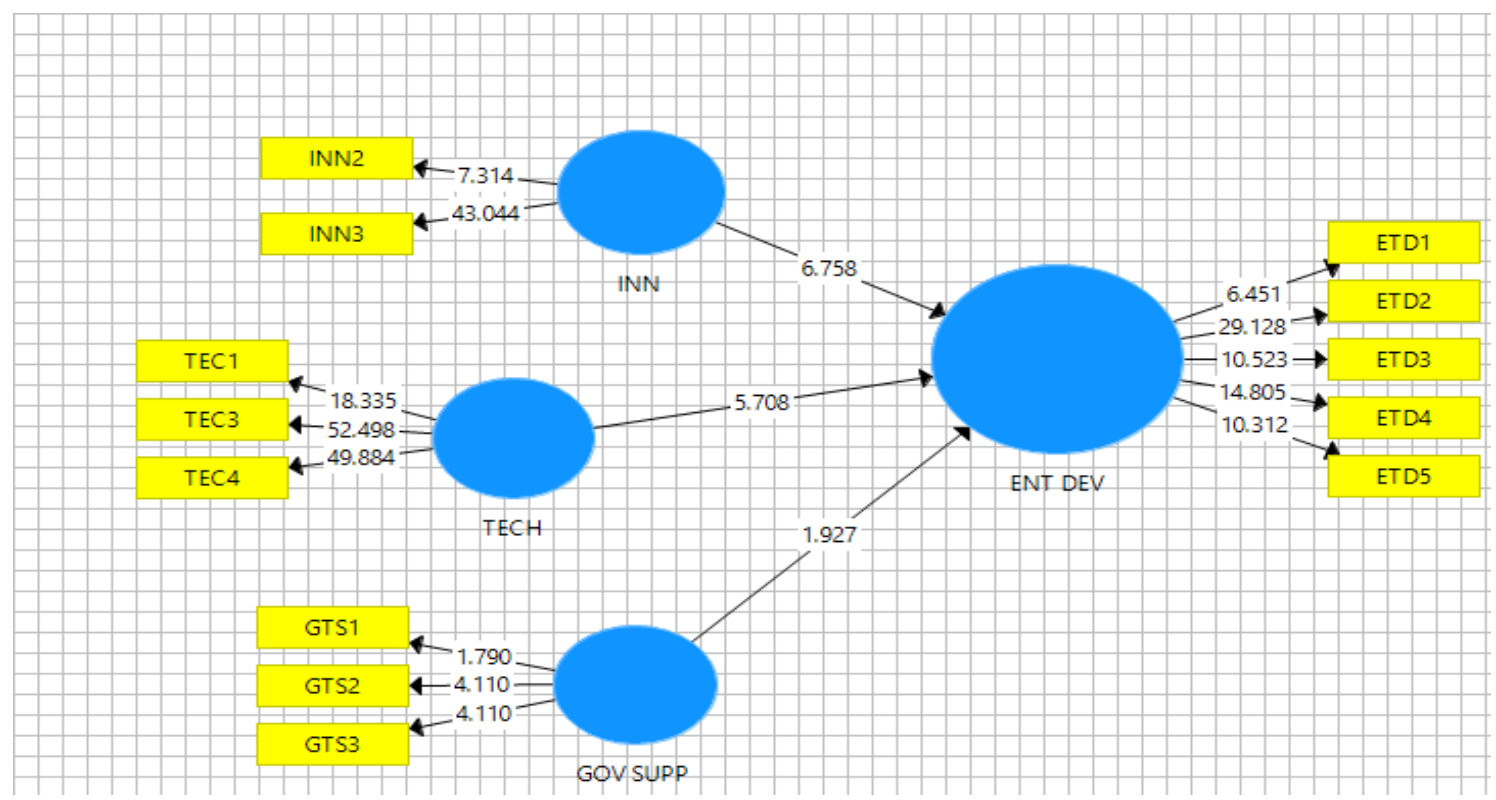

Figure 2. Structural model for direct relationship

Before testing for the moderating role of government policies on the relationship between technology, innovation and entrepreneurship development, it is important to determine the direct effect of government support, technology and innovation on entrepreneurship development.

Table 5. Direct Path Coefficient

\begin{tabular}{|c|c|c|c|c|}
\hline R Square: 0.654 & & & & \\
\hline Hypotheses & $\begin{array}{c}\text { Beta } \\
\text { Value }\end{array}$ & $\begin{array}{c}\text { Standard } \\
\text { Deviation }\end{array}$ & P value & Decision \\
\hline $\begin{array}{c}\text { Government Policies } \\
\text {-> Entrepreneurship } \\
\text { Development }\end{array}$ & 0.101 & 0.053 & $0.054^{*}$ & Rejected \\
\hline $\begin{array}{c}\text { Innovation -> } \\
\text { Entrepreneurship } \\
\text { Development } \\
\text { Technology -> } \\
\text { Entrepreneurship } \\
\text { Development }\end{array}$ & 0.090 & 0.075 & $0.066^{*}$ & Rejected \\
\hline
\end{tabular}

$\mathrm{P}$ value $<0.1^{*}$

It can be deduced from table 5 that government policies have a positive and significant effect on entrepreneurship development with ( $p$ value $0.054<0.1)$. Innovation has a positive and significant effect on entrepreneurship development with $(p$ value $0.066<0.1)$ and technology has a positive and significant effect on entrepreneurship development with has a positive and significant effect on entrepreneur development. ( $P$ value $0.058<0.1$ ). As a result the null hypothesis that stated; Government support, innovation and technology have no significant relationship on entrepreneurship development is rejected. Also the coefficient of determination $(R 2)$ was also assessed. From the PLS Path model estimation diagram (see Figure 1), the overall $R 2$ is found to be relatively strong. Threshold value of $0.25,0.5$ and 0.7 are often used to describe a weak, moderate, and strong coefficient of determination (Hair at el., 2013). In this case, the three constructs government support, innovation and technology can jointly explain $65.4 \%$ of the variance of the endogenous construct entrepreneurship development.

\section{Indirect Relationship (Moderator inclusive)}

The model shows the moderating effect of government support on the relationship between technology, innovation and entrepreneurship development. 


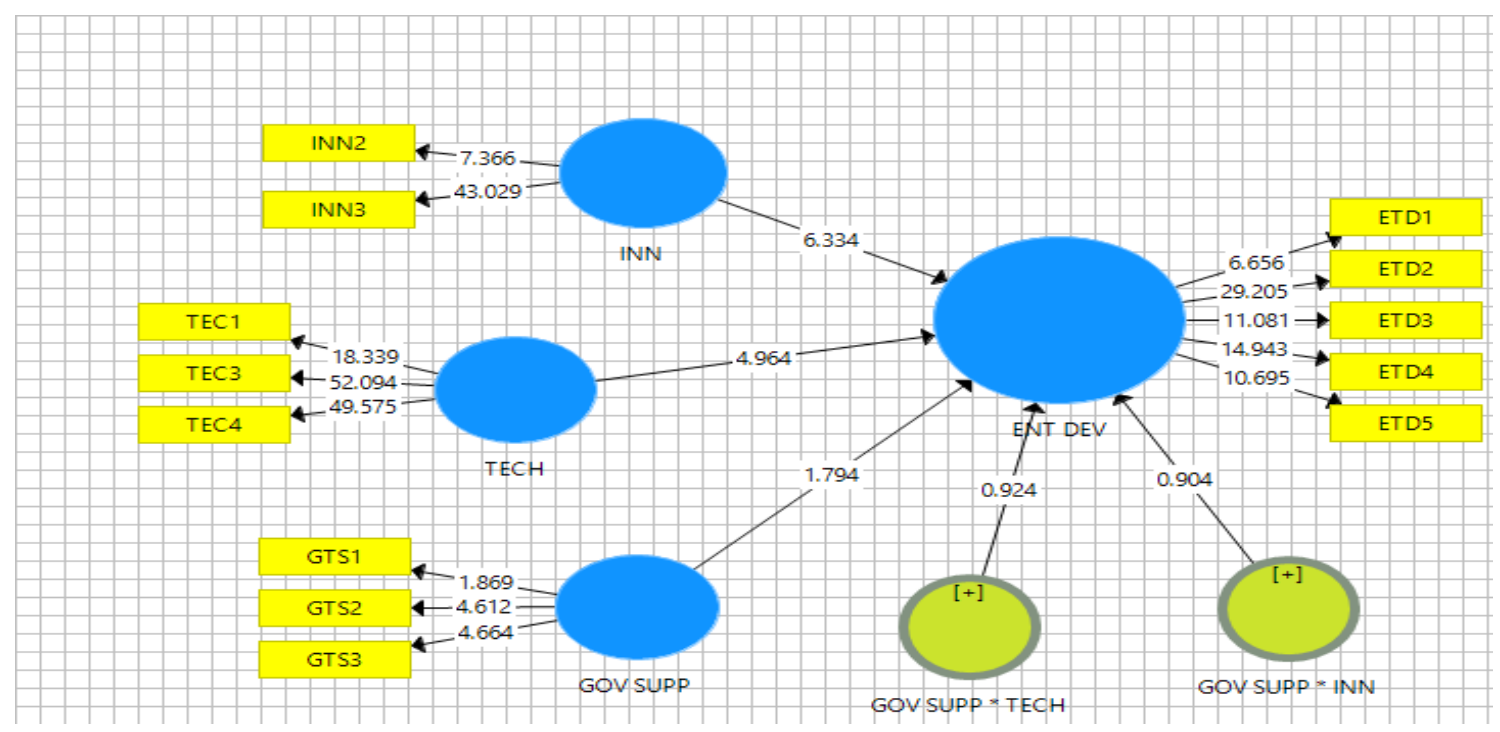

Figure 3. Structural model for indirect relationship

Table 6. Indirect Path Coefficient

\begin{tabular}{|c|c|c|c|c|}
\hline R Square: 0.759 & & & & \\
\hline Relationship & Beta Value & $\begin{array}{c}\text { Standard } \\
\text { error }\end{array}$ & P value & Decision \\
\hline Government Policies -> ED & 0.078 & 0.039 & $0.024^{* *}$ & Rejected \\
\hline Innovation-> ED & 0.104 & 0.042 & $0.041^{* *}$ & Rejected \\
\hline Technology -> ED & 0.118 & 0.041 & $0.048^{* *}$ & Rejected \\
\hline Government policies *Innovation -> ED & 0.510 & 0.056 & $0.000^{*}$ & Rejected \\
\hline Government Policies *Technology ->ED & 0.409 & 0.064 & $0.000^{*}$ & Rejected \\
\hline
\end{tabular}

$\mathrm{P}$ value $<0.05^{* *}, \mathrm{P}$ value $<0.01 *$ ED: Entrepreneurship Development.

The result indicated that a positive relationship exists between government policies on entrepreneurship development ( $p$ value $0.024<0.05$ ). The result also revealed that a positive relationship exists between innovation and entrepreneurship development ( $p$ value $0.041<0.05$ ). Additionally, the study found a significant positive relationship between technology and entrepreneurship development ( $p$ value $0.048<0.05$ ). The moderating result shows that government policies significantly moderate the relationship between innovation and entrepreneurship development ( $p$ value $0.000>0.01$ ). Finally, government policies significantly moderates the relationship between technology and entrepreneurship development ( $p$ value $0.000<=0.01$ ). From the PLS Path model estimation diagram with the inclusion of a moderator (see Figure 2), the overall $R 2$ is found to be stronger. In this case, the three constructs innovation and technology moderated with government support can jointly explain $75.9 \%$ of the variance of the endogenous construct entrepreneurship development.

\section{Effect Size}

The effect size of the exogenous variable on the endogenous variable was assessed by means of $f 2$ proposed by Cohen (1988), this was analysed in the table below.
Table 7. R-square Change and F-square Effect Size of Exogenous Factors

\begin{tabular}{|c|c|c|}
\hline Relationship & F square & $\begin{array}{c}\text { Effect } \\
\text { size }\end{array}$ \\
\hline Government Policies -> ED & 0.531 & Strong \\
\hline Innovation-> ED & 0.025 & Moderate \\
\hline Technology -> ED & 0.299 & Moderate \\
\hline Government policies *Innovation -> ED & 0.011 & Weak \\
\hline Government Policies *Technology ->ED & 0.009 & Weak \\
\hline
\end{tabular}

ED: Entrepreneurship Development.

Threshold value of $0.02,0.15$ and 0.35 are often used to describe a weak, moderate, and strong coefficient of determination. In this case, the effect size of 0.4356 is regarded as a strong effect. From table 7, specifically, dropping government policies will lead to a greater drop in the explained variance than dropping other variables. Government policies are thus the more important explanatory variable of the model.

The effect size of an interaction model is quite different from inner model. The interaction model can be estimated from:

$$
\begin{gathered}
F^{2}=\frac{R^{2} \text { model with moderator }-R^{2} \text { model without moderator }}{1-R^{2} \text { model with moderator }} \\
\qquad \begin{array}{c}
\frac{0.759-0.654}{1-0.759} \\
\mathrm{~F}^{2}=0.4356
\end{array}
\end{gathered}
$$


In this case, the effect size of the interaction model was 0.4356 which implies that the model has a strong effect.

\section{Conclusion and Recommendations}

The study, based on the findings, concludes that government policies, innovation and technology are strong determinant of entrepreneurship development in Nigeria. Entrepreneurship has many multiplier effects on the economy, it spurs innovation and fosters investment in people. Entrepreneurial activities have been found to be capable of making impact on the economy of a nation and quality of life of the people through economic growth; employment generation and empowerment of the disadvantaged segment of the population, which include women and the poor.

Similarly, government policies in this context moderate the relationship between innovation, technology and entrepreneurship development. To spur economic growth in Nigeria through entrepreneurship development, it is vital for government to provide more funds to support entrepreneurs who are willing to go into business and also support innovative ideas of student and non-student in Nigeria. Government should also put in place machinery that will curb corrupt practices as a recent SMEs report in Nigeria indicated that less than $5 \%$ of funds budgeted by government have so far reached SME's while failure is attributed to corruption. Government should enact policies that will encourage and promote the use of technology and support innovative ideas to bring economic growth through entrepreneurship development.

Finally, government should strive to reduce the cost of doing business in Nigeria, to the benefit of both entrepreneurial firms and other small businesses, by providing conducive to environment. To achieve this objective, infrastructural facilities, including good road network, stable power and water supply should be provided as a matter of priority. Security should be beefed up in both urban and rural communities and the problem of corruption should be realistically addressed.

The study focused on SMEs in Osun State; therefore findings may not be generalized on all SMEs in Nigeria. It is therefore important for future study to be conducted in different states of Nigeria to enable generalization of findings.

\section{REFERENCES}

[1] Akande, O. O., \& Oladejo, M. O. (2013). An appraisal of technological entrepreneurship development programmes on the performance of selected SMES in Lagos- Nigeria. Issues in Business Management and Economics, 1(December), 208-217.
[2] Aminu, M. I., (2015). Relationships between Organizational Memory, Intellectual Capital, Entrepreneurial Orientation, Dynamic Capabilities and Firm Performance in Nigeria. Doctoral Thesis, Universiti Utara, Malaysia.

[3] Amue, G. J., Igwe, S., \& Abiye, H. (2014). Ict entrepreneurship and small business innovation: a mechanism for sustainability. European Journal of Business and Social Sciences, 3(6).

[4] Bhat, S. A., \& Khan, R. A. (2014). Government Policy Ecosystem for Entrepreneurship Development in MSEs Sector. Munich Personal RePEc Archive, (54540).

[5] Bubou G. M \& Siyanbola W. O., (2010). 'Science and Technology Entrepreneurship for Socio-Economic Development in Africa (SEEDA). In proceedings of the Third Annual International Conference on Entrepreneurship.

[6] Bulsara, H. P., \& Gandhi, S. (n.d.). Techno-innovation to Techno-entrepreneurship through Technology Business Incubation in India: Entrepreneurship Networks Human Resource Management, 56-67.

[7] Fornell, C. \& Larcker, D. F. (1981). Evaluating Structural Equation Models with Unobservable Variables and Measurement Error. Journal of Marketing Research, 28(1): $39-50$.

[8] Friedman, B. A., (2011). The Relationship between Governance Effectiveness and Entrepreneurship. International Journal of Humanities and Social Science, 1(17): p. 221.

[9] Gangi, Y.A. and Timan, E., (2013). An Empirical Investigation of Entrepreneurial Environment in Sudan. World Journal of Entrepreneurship, Management and Sustainable Development. 9(2/3): p. 168-177.

[10] Goutam, S., \& Sarkar, R. (2015). Role of Technology in Entrepreneurial Development: Facilitating Innovative Ventures, 5(1), 239-244.

[11] Hair, J., Black, W., Babin, B., \& Anderson, R. (2014). Multivariate Data Analysis. 7th ed. Pearson New International Edition: UK

[12] Hosseini, F., Lashgaara, F., \& Hosseini, S. J. F. (2014). The Role of ICT in Entrepreneurship Development from Experts View of Agriculture Organization of Tehran, 4(December), $152-156$.

[13] Hussain, M. F., Asif, M., Ahmad, N., \& Bilal, R. M. (2011). Impact of Innovation, Technology and Economic Growth on Entrepreneurship, 1(1), 45-51.

[14] Ihugba, O.A., Odii, A., and Njoku, A., (2014). Theoretical Analysis of Entrepreneurship Challenges and Prospects in Nigeria. International Letters of Social and Humanistic Sciences, 5: p. 21-34.

[15] Isreal G. D. (2013). Determining Sample Size. Retrieved September 8, 2016 from http://www.sut.ac.th/im/data/read6.pdf

[16] Juma C, Agwara H (2006). Africa in the global knowledge economy: strategic options. Int. J. Technol. Globalisation. 2 (3-4): 218-231.

[17] Moghimi, M. (2008). Stimulating entrepreneurial development. Entrepreneur Magazine. 1 (2):4-8. (In Persian) 
[18] Obaji, N. O., \& Olugu, M. U. (2014). The role of government policy in entrepreneurship development, 2(4), 109-115. http://doi.org/10.11648/j.sjbm.20140204.12

[19] Okpara, F. (2007). The Value of Creativity and Innovation in Entrepreneurship. Journal of Asia Entrepreneurship and Sustainability. Volume III, Issue 2.

[20] Onwuka, E. M., Ugwu K. E, \& Kalu, A. U. (2014). The Effect of Policy Measures on Entrepreneurship Development Analysis of Nigeria's Experience. European Journal of Business and Management, 6(23), 270-277.

[21] Oyewale, I. O., Adeyemo, S. A., \& Ogunleye, P. O. (2013). Technological Innovation: An Imperative Tool for Entrepreneurship Development in Nigeria. Australian Journal of Business and Management Research, 3(8), 4147.

[22] Siyanbola, W. O., Aderemi, H. O., Egbetokun, A. A., \& Sanni, M. (2011). Framework for Technological Entrepreneurship Development: Key Issues and Policy Directions, 10-19. http://doi.org/10.4236/ajibm.2011.11002

[23] Khanduja, D., Khanduja, J. \& Singh S. S. (2008). The ambience of incubated entrepreneurship in Indian economy',
South East Asia, Australia and New Zealand (SEAANZ) 2008 Conference Proceedings.

[24] Li, D., \& Liu, J. (2014). Dynamic capabilities, environmental dynamism, and competitive advantage: Evidence from China. Journal of Business Research, 67(1), 2793-2799. doi:10.1016/j.jbusres.2012.08.007

[25] Sathe, V. (2006). Corporate entrepreneurship: Top Managers and New Business Creation. Cambridge: Cambridge University Press.

[26] Schumpeter, J. A. (1934). The Theory of Economic Development. Cambridge, USA: Harvard University Press.

[27] Sharma, M. K \& Bhagwat, R. (2006), "Practice of information systems, an evidence from select Indian SMEs", Journal of Manufacturing Technology, Vol. 17 No. 2, pp. 199-223.

[28] Tende, S. B. A. (2014). Government Initiatives Toward Entrepreneurship Development in Nigeria, 8(1), 109-120.

[29] Urbach, N. \& Ahlemann, F. (2010). Structural equation modeling in information systems research using partial least squares. Journal of Information Technology and Theory 11(2): 5-36. 